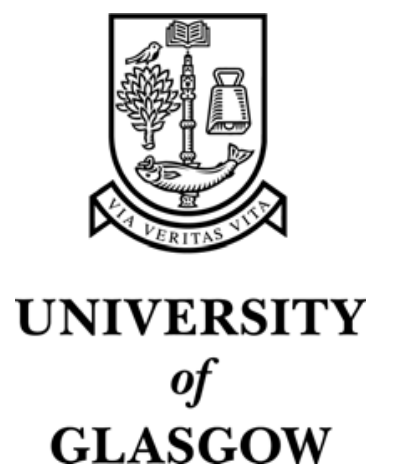

Davidson, J. and Powney, J. and Wilson, V. and Hall, S. and Mirza, H.S. (2005) Race and sex: teachers' views on who gets ahead in schools? European Journal of Teacher Education 28(3):pp. 311-326.

http://eprints.gla.ac.uk/2846/ 


\title{
Race and sex: teachers' views on who gets ahead in schools?
}

\author{
Julia Davidson , Janet Powney, Valerie Wilson, Stuart Hall and Heidi \\ Safia Mirza \\ University of Glasgow, UK
}

\begin{abstract}
The research reported here was part of a large study of the impact of age, disability, race and sex on the teaching profession in England. The basic question asked in this research was how do these factors interact with career aspirations and achievements of classteachers, promoted teachers and headteachers? There were three different data sources: a large postal survey drawn from diverse geographic regions across England with over 2000 respondents; faceto-face individual interviews with over 100 teachers in 18 case study schools from across all of the main regions of England; discussions with special interest groups of teachers. Not surprisingly, the answer to the above question was complex. Nonetheless, the paper's conclusion highlights some of the noteworthy themes across this broad sample of teachers from primary, secondary and special schools.
\end{abstract}

Les travaux de recherche de'cris dans cet article ont fait partie d'une large e'tude sur l'impact de l'age, des handicaps, de l'origine ethnique et du genre sur les professions de l'enseignement. L'une des questions aborde'es dans cette recherche e'tait de savoir comment ces facteurs interagissaient avec les aspirations professionnelles et les carrie 'res des enseignants, administratifs et chefs d'e'tablissement. Trois principales sources d'information ont e'te' utilise'es: un sondage par courrier de plus de 2000 personnes, couvrant différentes régions ge'ographiques de l'Angleterre; des entretiens individuels avec une centaine d'enseignants de 18 écoles cibles, reparties sur les principales re'gions de l’Angleterre; des discussions avec des groupes de travail d'enseignants. De manie`re non surprenante, la réponse a` la question ci-dessus s’est ave're'e complexe. Ne'anmoins, cet article met en évidence un ensemble de the`mes significatifs a` travers ce large groupe d'enseignants issus du primaire, du secondaire et d’institutions spécialise'es.

La investigación que se presenta aquı́ formó parte de un largo estudio sobre el impacto que tenı́a la edad, discapacidad, diferencias de etnia y género en la profesión de maestro en Inglaterra. Una de las principales cuestiones a contestar en la presente investigación fue co'mo estos factores interactu'an en las aspiraciones profesionales de maestros, jefes del departamento y directores, se presentan en este artı́culo. Hubo tres principales fuentes de datos. Estas incluı́an: una amplia encuesta por correo la cual tuvo en cuenta diversas regiones de la geografía de Inglaterra, con cerca de unas 2000 personas encuestadas; entrevistas individuales cara a cara a unos 100 maestros en 18 estudios de casos de escuelas a trave's de todas las principales regiones de Inglaterra; y discusiones

*Corresponding author. The SCRE Centre, Faculty of Education, University of Glasgow, St Andrews Building, 11 Eldon Street, Glasgow G3 6NH, UK. Email: julia.davidson@scre.ac.uk

ISSN 0261-9768 (print)/ISSN 1469-5928 (online)/05/030311-16 \#2005 Association for Teacher Education in Europe DOI: 10.1080/02619760500269459

con grupos interesantes de maestros. No nos debe sorprender que las respuestas a las preguntas comentadas anteriormente fueran complejas de resolver. De todas formas las conclusiones del artı́culo dan luz a algunos de los temas significativos a trave's de la amplia muestra de maestros de escuelas de primaria, secundaria y escuelas 
especiales.

Die hier pra“sentierte Forschungsarbeit war Teil einer umfassenden Studie, die sich mit der Auswirkung von Alter, Behinderung, ethnischer Herkunft und Geschlecht auf den Lehrberuf in England auseinandersetzt. Die wesentliche Frage, die in dieser Forschungsarbeit gestellt wurde, lautete wie folgt: wie wirken sich genannte Faktoren auf Karriereaspirationen und Leistungen von Klassenlehrern, befo“rderten Lehrern und Schulleitern aus? Die Daten wurden aus drei Hauptquellen bezogen; dazu geho“ren: eine umfassende, geographisch breitgefa“cherte Postumfrage in England, auf die u“ber 2000 Befragte antworteten; perso“nliche Gespra“che mit u“ber 100 Lehrern aus 18 zu Fallstudien herangezogenen Schulen in den Haupregionen Englands; und Diskussionen mit Lehrern, die bestimmte Interessengruppen vertreten. Die Antwort zu der oben genannten Frage war erwartungsgema“"ss komplex. Nichtsdestoweniger werden in dieser Arbeit einige der Themen hervorgehoben, die Lehrer aus dem Prima“r-, Sekunda"r-und Sonderschulbereich fu“r besonders erwa“hnenswert hielten.

\section{Introduction}

In 2006 a directive from the European Union requires all forms of discrimination (age, disability, race, sex, religious affiliation or belief and sexual orientation) to be illegal in the workplace. Traditionally teaching is perceived to be an equitable career, open to all who choose to go through the prescribed stages of recruitment and training (Maclean, 1992). It is now being recognized that those who choose to become teachers are far from homogeneous in their make up (Maylor et al., 2003). Teachers are a diverse professional group, the members of which are differentiated by a number of characteristics. Some of these attributes include age, sex, race, religion, cultural heritage, sexual orientation, marital status, family circumstances, acute and chronic mental and physical disabilities and other health problems. Although many might regard it as unethical to discriminate on the grounds of age, disability, race and sex, it is debatable whether the incoming legislation can achieve practical changes in the education workforce in schools.

So how is the profile of the profession shaping up to meeting the challenges of the equal opportunity requirements of the incoming legislative framework? Few previous studies have considered the interplay of factors that may contribute to career disadvantage in the teaching workforce. First, some published evidence is presented about the profession's statistical profile in terms of age, disability, race and sex in England. Then the paper turns to our own investigation into teachers' attitudes about the effects of these factors on their careers. We conclude by highlighting some of the implications of their views for the future profile of teachers in schools. Unless otherwise stated, the statistical data presented on the teaching population in England comes from the Department for Education and Skills (DfES) (2003a). 


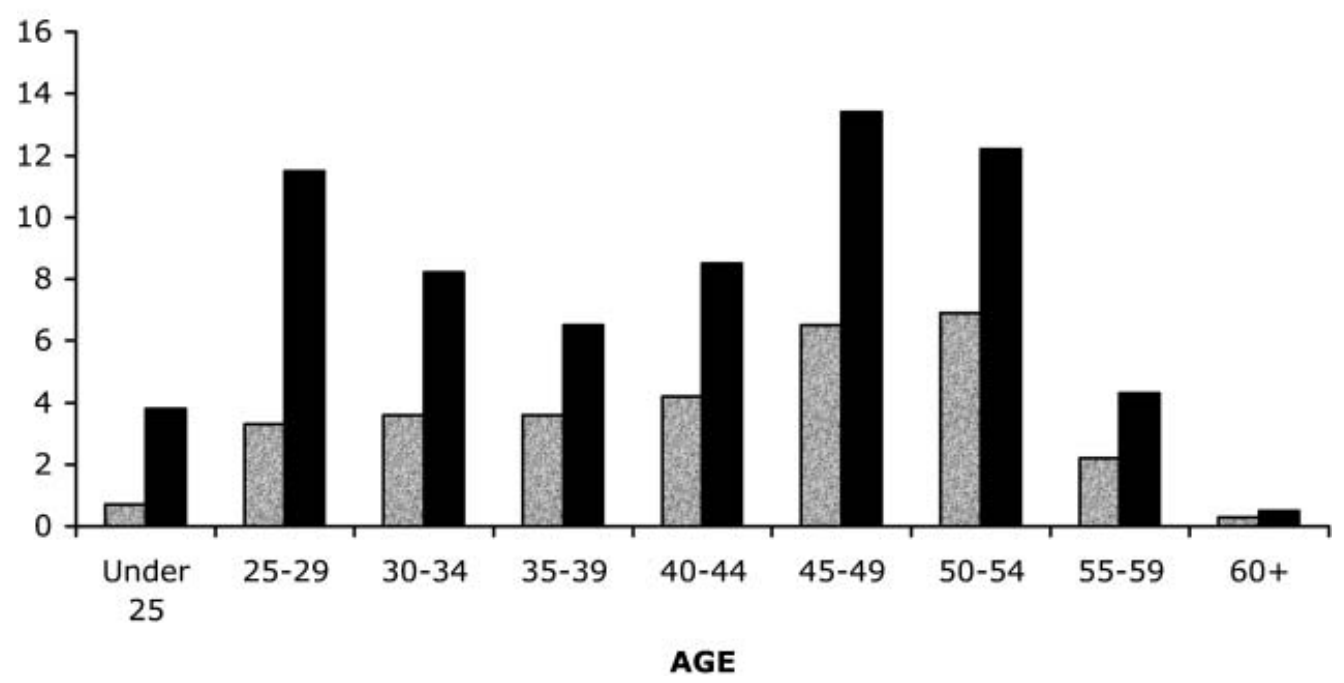

Figure 1. Proportion of full-time teachers in the teaching profession in England by age and sex (DfES, 2003a)

The national picture: age, disability, race and sex

Age

The distribution of teachers' ages is not uniform: it reflects the age imbalance within the general population. The majority of teachers (59\%) tend to be 40 or over, with less than one in five (19\%) under 30. This pattern is clearly shown in Figure 1. In every age group there are more females than males. An estimate of the median age of males is 48 , whilst the comparative figure for females is only 42. These statistics, together with others discussed below, have fuelled speculation about the progressive 'ageing' and 'feminization' of the profession (Hutchings, 2001). Not surprisingly, there is a big drop-off in the proportion of female teachers in their 30s and early 40s during the child-bearing years. There is a bulge in the distribution for teachers in their mid 40s and early 50s. Another feature of Figure 1 is that the numbers of both sexes drop off disproportionately in the over 55 age groups. The proportion of teachers in the 55-59 age group is less than half that of the younger age group, 5054 and in the older over 60s group the proportion of teachers is less than $2 \%$.

\section{Disability}

Nearly $20 \%$ of the adult population of working age report that they have some sort of long-term physical or mental disability, although this may not necessarily be work limiting (National Statistics, 2002b, pp. 415-427). The number is higher for men than women (3.7 million men, compared with 3.4 million women). The overall proportion of students with disabilities in higher education was about $5 \%$ (Tinklin et al., 2003). There has been little substantive research undertaken on teachers with disabilities working in mainstream schools. The General Teaching Council of England (GTCE) (2002, personal communication) estimated that the corresponding figure for teachers with disabilities was very much lower, at $0.05 \%$. Hence, it seems unlikely that teaching is representative of the overall working population in terms of the broad definition of disability (which unless otherwise specified is used throughout this paper). 
The proportion of the UK population from a minority ethnic group is estimated at about 8\% (National Statistics, 2002a). Minority ethnic teachers represent about 5\% of the teaching workforce in England (DfES, 2004). A minority of teachers have refused to disclose their ethnic origin. Even so, it is generally accepted in the literature that minority ethnic teachers are under-represented in the teaching workforce and are often working in schools where their heritage group is well represented among the students at the school and in the local community (Carrington et al., 2000, 2001). Nonetheless, McCreith and Ross (2002) reported in a recent survey that $20 \%$ of non-minority ethnic teachers with 15 years or more experience were either headteachers or deputy headteachers, whereas the corresponding proportion for minority ethnic staff was significantly lower.

\section{Sex}

The vast majority of teachers in England are female (see Figure 1). Just under one-third (31\%) of fulltime qualified teachers are male. Men are more likely to be found in secondary schools than primary schools. Nearly half (46\%) of secondary teachers are male. However, the proportion of primary teachers who are male is less than one-fifth (16\%). Indeed, the proportion of men entering primary teaching has declined (to less than 14\%) over the last decade and most teach in the upper stages of primary school (Thornton \& Bricheno, 2000; Garner, 2002, p. 13).

On the other hand, there are disproportionately few female headteachers. A numerical breakdown of the sex of teachers in the three education phases, primary secondary and special, is given in Table 1. Table 1 also shows the comparative breakdown by sex for teachers in the senior management posts of headteacher and deputy headteacher. Although the bulk of primary school teachers (84\%) were female in 2001, women were only somewhat more likely than men (61 compared with $39 \%$ ) to be employed in headships positions in primary schools. Howson (2002, p. 32) pointed out that women were particularly well represented in a survey of London primary schools, holding $80 \%$ of headships.

Women make up over half (53\%) of the secondary teaching population, but are still underrepresented in secondary school senior management positions, particularly headships (Howson, 2002, p. 32). Less than one-third (31\%) of secondary headteachers are women. In all sectors the proportion of women in headteacher and

Table 1. Percentage of the whole teaching population, headteachers and deputy headteachers in England in each education phase by sex in 2001 (DfES, 2003a)

Phase and post Numbers of teachers (\%)

Female Male Total

(a) Whole teaching population Primary and nursery Secondary Special (and pupil referral units)

(b) Headteachers and deputy headteachers

Primary and Nursery

Headteacher

Deputy headteacher

Secondary

Headteacher

Deputy headteacher

Special (and pupil referral units)

Headteacher

Deputy headteacher

142,700 (84\%) 98,100 (53\%) 9600 (68\%) 


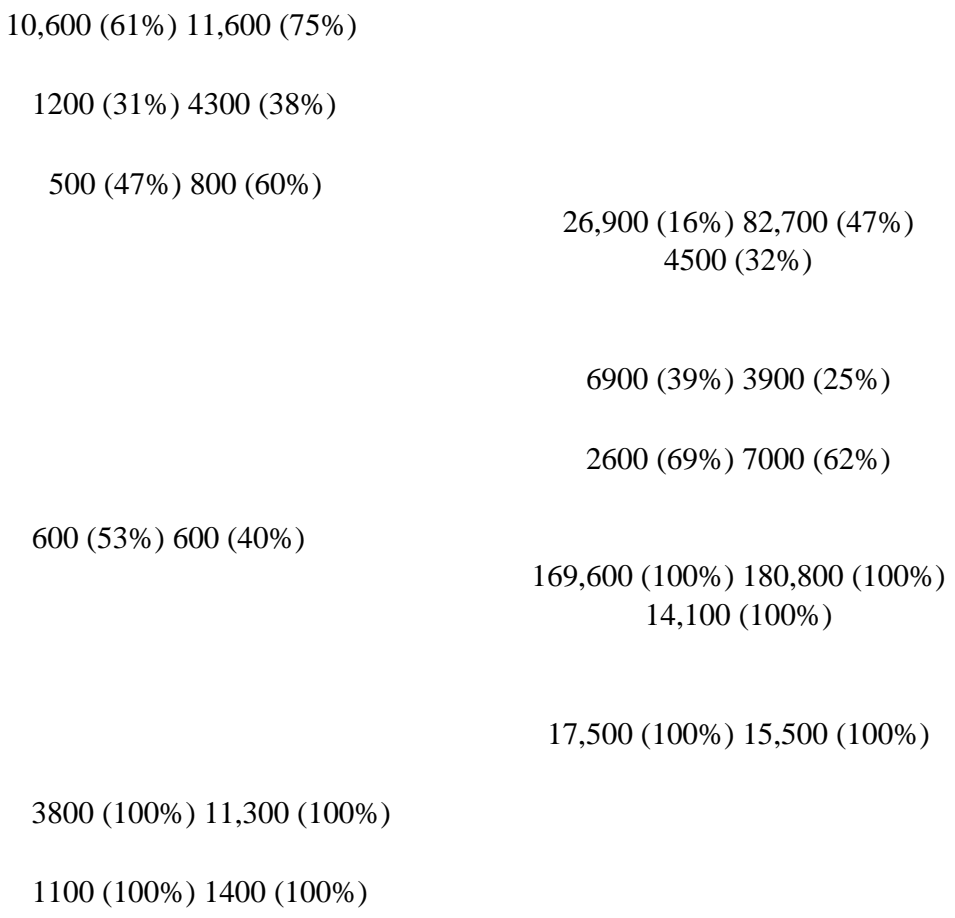

deputy headteacher positions has recently increased (DfES, 2003a). Moreover, if the numbers of all the headteachers and deputy headteachers are combined across sectors then the majority (57\%) are female (compared with $43 \%$ male). Looking only at headteachers we found $55 \%$ are women $(12,300)$ and $45 \%$ are men $(10,100)$.

Part-timers and supply teachers are overwhelmingly female (National Union of Teachers [NUT], 2001). The majority of part-time and supply teachers are women who return to work after a break to have a family. A key issue for these women is the flexibility that teaching offers them compared with other jobs: it allows them to fit in work with their family commitments. The proportion of part-timers has steadily increased from 4 to 8\% between 1985 and 2001.

The preceding section presented a brief profile of the teaching profession in England in term of age, disability, race and sex. The focus of this paper now shifts to presenting some of the findings from our recent large-scale study of teachers' perceptions on their career aspirations and achievements. First the research methodology is described briefly below.

\section{Research design}

This paper is based on a study undertaken by The Scottish Council for Research in Education (SCRE) and Middlesex University between January 2002 and April 2003. It comprised a combination of quantitative and qualitative approaches (detailed in Powney et al., 2003), including the following.

N A large-scale postal survey of approximately 13,000 teachers from over 1000 randomly selected schools in one-third of the English Local Education Authorities covering all of the main regions. The questionnaire is appended to the full report (Powney et al., 2003). The survey categories were approved by the Commission for Racial Equality and the Disability Rights Commission.

$\mathrm{N}$ In-depth case studies of 18 schools chosen by their local authorities as representative of interesting 
practice in terms of equal opportunities. The case studies included interviews with 109 staff. Cases covered all of the main geographic regions in England. A contextual profile of case study schools broken down by phase, location and proportion of minority ethnic students, is given in Table 2 . The study involved 10 primary schools, 6 secondary schools and 2 special schools.

N Several workshop discussions outside school settings were conducted with interested individuals, groups, unions and professional associations.

The purpose of using these different methods was to adopt the grounded analysis approach of Glaser and Straus (1967) and use triangulation of the data sets to look for commonalties and consistent themes. Some striking features of the findings are

Table 2. Profile of the 18 case study schools

School no. Phase Location Proportion of minority ethnic students

Primary i ii iii iv v vi vii viii ix x

Secondary xi xii xiii xiv xv xvi

Special xvii xviii Urban/suburban Suburban Rural Urban Suburban Rural Urban Urban Suburban/rural Suburban

Urban Suburban Rural Urban Suburban Urban

Suburban Suburban High Low Low High None Low High High Low Low

High Medium Medium High Low High

None High

a

Low\#5\%; 5\%,medium,50\%; high\#50\%.

elaborated below and their broader implications for schools in England are then considered.

Findings

\section{Respondents' profile}

Overall, the profile of teachers who responded to our postal survey, 2158 individuals, was broadly similar to the profile of the whole teaching profession in England. The proportion of responses from the secondary sector (52\%, 1119 respondents) was slightly greater than the primary sector $(39 \%, 839$ respondents). However, given that we sought to maximize responses from minority ethnic teachers, a majority of whom teach in secondary schools, this imbalance was not unexpected. Table 3 shows some of the comparative descriptive statistics of the survey respondents and the overall teaching population in terms of age, disability, race and sex. Hence, it is likely that the respondent sample slightly over-represents minority ethnic groups and those with disabilities. Further details of informants and the statistical analysis are presented in Powney et al. (2003). Unless stated otherwise, the quantitative findings reported here were statistically significant in $x^{2}$ tests at the $1 \%$ level.

In the case of race there were analytical restrictions due to the relatively small numbers in some of the minority ethnic groups. In total, the proportion of minority ethnic respondents was $18 \%$ (384 respondents). Hence, the balance of the discussion of the various factors and their interactions, including race, was 
Table 3. Comparisons of the characteristics of the postal survey respondents with the overall teaching population in England in 2001 (DfES, 2003a, b, 2004) in terms of age, disability, race (designated by ethnic origin) and sex

Characteristic (no. Category Postal survey Teaching population of respondents)

Sex (n52158) Age (n52158)

Ethnic origin (n52135)

Disability (n52158) Female Male ,30 30-39 40-49>50 and over Not specified Asian or Asian British Black or black

British White or white British Other, Mixed, Chinese Not specified Yes None declared Missing

70\% 30\% 18\% 22\% 32\% 27\% 1\% 7\% 3\% 87\% 2\% 1\% 5\% 94\% 1\% 69\% 31\% 19\% 22\% 33\% 26\% - 2\% 2\% 74\% 1\%

0.05

somewhat limited and uneven due to statistical limitations. It should also be noted that caution must be exercised in generalizing from our survey data about the attitudes of male primary school class teachers because they were also an underrepresented group: there were only 24 such respondents (compared with 219 female primary classteachers). With the above provisos, we now proceed to make some observations based on the evidence from the survey data, which was to a great extent supported by the views of informant groups in the other key sources of data, the case studies and special interest groups.

\section{Respondents' main reason for being a teacher}

The majority of respondents' main motivation for entering teaching, irrespective of their personal background, was that they wanted to 'make a difference'. Case study informants and questionnaire respondents saw themselves first and foremost as teachers (rather than, for instance, from a particular minority ethnic group or sex or some combination of both). The school cases suggested that few appeared to have planned their career progression. Some positively chose not to go for promotion, but all expected their job to be interesting, demanding, creative and rewarding. As one male interviewee explained: 'I am in my 17th year of teaching and still love it in the classroom' (secondary class teacher, school xiv).

However, teachers in the special interest groups perceived a combination of factors, such as age, disability, race and sex, as crucial determinants of their circumstances. In the following section we highlight some key findings related to these factors in terms of the professional experiences of class teachers, promoted teachers with some management responsibilities and senior managers, including headteachers, in this study. Then, as a corollary, we focus on some issues specifically around teachers who get ahead in schools in terms of being in the senior management posts of headteacher and deputy headteacher. How did the profile of the 2158 teachers who responded to our postal survey interrelate with their promotional aspirations and achievements? Various aspects of this complex question are addressed below.

Age

Age was seen as very important or somewhat important to most survey respondents $(80 \%)$ for teachers' promotion prospects. In the case studies age was often perceived as interacting with other 
factors, particularly with race and sex. Hence, for simplicity some of these key age-related issues are discussed in subsequent sections. In the case studies age was often seen as an inhibitor of promotion by older staff. Occasionally newly qualified female teachers mentioned that looking young inhibited their ability to teach older boys in secondary schools: they perceived that this had already limited their chances of promotion.

Older female informants in supply and part-time positions often mentioned that they felt that their careers had not progressed as satisfactorily as their male counterparts. An older female case study informant in a supply post was ambivalent about the advantages of temporary work and perceived that she was disadvantaged in applying for permanent posts due to her age. Although she felt that she was a respected employee and guaranteed work and she had been on training courses to update her skills, she reflected that she had been passed over unfairly for permanent positions. For promotion to headteacher age was an important issue for deputy headteachers. As one female 48 year old deputy head articulated:

My daughter is in Year 8. I've got 18 months. I've got to get moved [to a headship] before she's in Year 11. After that once she has done her exams, I'll be too old. Some might say I'm too old now! It's not a very big window really. (Deputy head, secondary school xv)

\section{Disability}

A large minority of survey respondents (43\%) perceived that disability was very important or somewhat important for teachers' promotion prospects. Even so, the number of teachers with disabilities in our postal survey was too low (5\% of postal respondents, 107 people) to make meaningful generalizations about this group. Nonetheless, the survey shows that disabled teachers feel more isolated from colleagues. However, from the case studies and special interest groups the following observation is noteworthy. There was clearly a tension for some informants between being accepted as a teacher and drawing attention to their special needs. Interviewees pointed out that being made to feel different from other staff was not always welcomed. For example, some staff with disabilities reported being asked 'How will you cope?' not 'How can we help you to be a good teacher'? Teachers with disabilities in special interest groups reported that they felt quite isolated, especially if they had become disabled later in life. As one teacher explained: 'I attended the ... conference and that was the turning point. I found out that I was not alone and that all the people there had been through [isolation]' (disability workshop informant).

\section{Race}

Only a quarter of all survey respondents saw ethnicity as very important or somewhat important in teachers' promotion prospects. However, 60\% of respondents (230 out of 384) from minority ethnic groups regarded ethnicity as being of some importance in promotion. Indeed, $41 \%$ of this group (153 out of 384) believed it had had a negative influence on their careers. A case study minority ethnic promoted teacher emphasized that schools with high proportions of minority ethnic students need more minority ethnic staff:

This school has over $60 \%$ ethnic minority pupils and yet has only 2 mainstream Asian teachers. ... We need to get good graduates. The routes in and funding are important. On the financial side, the money for teaching is about $£ 4000$ less that other similar ICT jobs. ... There is a lot of moaning and whinging on the part of teachers but there are a lot of problems with the long working hours, stress and bureaucracy. (Promoted secondary teacher, school xi)

This informant perceived that increased financial rewards would be a positive enticement into teaching for minority ethnic graduates. Evidence from the postal survey responses confirmed this view: Minority ethnic teachers were much more likely to be interested in better pay (14 versus 10\% 
for the majority ethnic respondents).

Moreover, some of the workshop informants believed that schools have not been especially proactive in implementing measures that would attract staff from minority ethnic groups. Even in a successful and happy case study school, a member of the senior management team believed that it would not be a 'comfort zone' for teachers from minority ethnic backgrounds since 'the overwhelming proportion of pupils and all teachers were white' (secondary school xiii). Indeed, some of the minority ethnic staff felt more comfortable in schools where they were not identified because of their 'difference' and hence preferred to work in schools that were culturally diverse. Some minority ethnic female informants preferred to work in primary schools than secondary schools because the staff complement was more likely to be all female

(e.g. primary school i). Some other case study informants felt that their minority ethnic background limited their choice of school unfairly. Three minority ethnic group informants elaborated their diverse experiences and perceptions, thus:

\footnotetext{
Ethnicity, I feel it is has been an issue. ... I've discussed it quite openly with the Head. ... I don't want to come across as only suitable to teach in these [culturally diverse] schools. My present Head is very supportive in a proactive way. I have had negative feedback in highly populated white schools. They said sorry we can't give you the post, because you haven't got the experience. I don't think this is a valid excuse! Then you find out that another newly qualified teacher has got the post! (Primary class teacher, school vi)

How trained, how inducted, what professional development ... these are not the issues.

Racism is the main issue. (Special interest group discussion) I don't know whether my ethnicity and sex have worked in my advantage because of their under-representation. I'd love to be assured that it was who I am and not what I look like. ... People say to me that they know they have made the right choice. (Male primary class teacher, school vi)
}

\section{Sex}

A minority of survey respondents (37\%) thought that sex was of some importance or very important. In this context it is worth mentioning that the majority (70\%) of survey respondents were female. Teachers in one case study school expected males to get quicker promotion than female teachers in primary schools (primary school ix). Informants in another case study school believed that such expectations seem to arise early in some teachers' careers, even in training (primary school vi), and some believed that it becomes a self-fulfilling prophecy, as women tend not to apply for promotion.

Indeed, survey males were more than twice as likely as females to seek promotion at every opportunity (7 compared with 3\%). The survey group most interested in promotion were minority ethnic males (12\%). Just over a quarter $(27 \%)$ of the survey respondents were not interested in promotion: these were most likely to be white females (31\%), then white males (26\%), followed by minority ethnic group females (14\%) and, finally, minority ethnic males (12\%). Overall, primary school respondents were less likely than teachers from secondary schools to be interested in promotion. This finding was consistent across the sex. The interaction between sex and other factors, such as race, is discussed below.

\section{Interactions between age, race and sex: who gets ahead in schools?}

Finally, we investigate the postal survey respondents' levels of promotion and how these levels interact with their age, race and sex. To simplify the analysis respondents were grouped into three broad categories: senior management, including headteacher, deputy and assistant headteachers; class teachers with no management responsibilities; a third group who indicated that they had some managerial duties or responsibilities. 
Minority ethnic respondents were less than half as likely as their other colleagues to hold senior management posts. This fact is clearly illustrated in Figure 2. Just over one-third of majority ethnic males had senior posts, compared with fewer than $20 \%$ of the female majority ethnic staff. In comparison, only $9 \%$ of minority ethnic males and $4 \%$ of minority ethnic females held such positions. If we divide the senior management posts into two age groups (the under $45 \mathrm{~s}$ and the $45+$ ) the pattern is

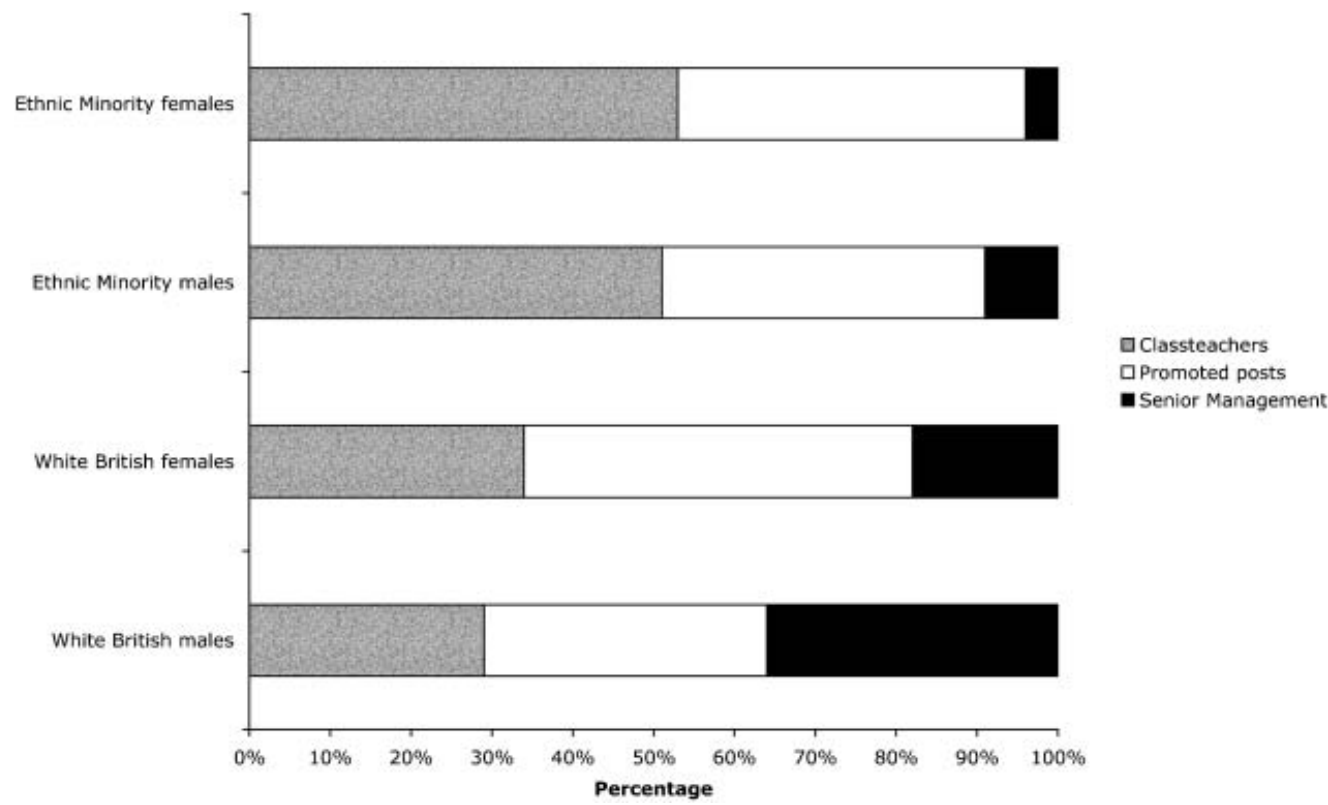

Figure 2. Proportion of survey respondents in senior management posts (e.g. headteachers and deputy headteachers), promoted posts with some managerial responsibilities and classteachers by ethnic origin and sex

still consistent: minority ethnic teachers were under-represented. Among the younger respondents (under 45), 12\% of majority ethnic respondents are in senior posts, whereas the corresponding figure for minority ethnic teachers is only 5\%. Among older teachers (45 and over) $35 \%$ of majority ethnic teachers are in promoted posts compared with $13 \%$ of minority ethnic teachers. Indeed, one member of a discussion group described how the process of seeking promotion could be demoralizing and affect self-confidence:

With women and ethnic minorities always finding it difficult to gain promotion, they have low self-esteem. Then when on the job they find that they are just as good if not better than their colleagues who are being promoted, this makes them seek management positions just as anyone else who is competent at their job. (Special interest group female discussant)

Indeed, another participant claimed: ‘[teachers] expect to have a tall, handsome, male headteacher and would be surprised to find a small Asian female head' (special interest group female discussant).

Overall, there is no obvious suggestion from the younger group of postal survey respondents with some managerial responsibilities that there is an increase in minority ethnic representation. Moreover, feedback from the minority ethnic group of informants indicated that they often feel their careers are still disadvantaged despite extensive training and qualifications and that this can result in their being deemed 'over-qualified' and/or too experienced by potential employers, for example:

I was usually more qualified than people on interviewing panels. The outcome is usually a rejection. (Special interest group female discussant) It does not matter how competent you are in all aspects of 
mainstream and special teaching and management/organization/leadership skills, as a black professional, you have no chance of progressing. (Special interest group female discussant)

Indeed, an older minority ethnic male teacher explained clearly the dilemma he faced when trying to break through what he perceived to be the 'white' ceiling. It would be easy for him to get positions in schools with 'ethnically mixed' catchments, but to gain experience in a range of school contexts meant getting a position in an 'all-white' school. This had proved problematic because the local headteachers of 'white' schools had not encouraged him to apply for any vacant posts. He noted that this problem would be less extreme in London, where both ethnic diversity and teacher vacancy levels are highest. However, he pointed out that he thought that most teachers could not uproot their families and move somewhere else. Nonetheless, younger interviewees without family commitments talked about the strategies they had adopted to seek and gain promotion that generally involved changing schools and also their places of residence.

Case study informants revealed why some teachers, especially majority ethnic females are not interested in promotion. One case study female class teacher, who had previously been a headteacher, explained the demands she had felt upon her in her prior post:

There was definitely a conflict between work and home. We were job sharing a headship and a deputy. Male colleagues thought it was funny. I would say that myself and my colleague did quite a good job. In the past [in other schools] I have heard people say, what we need for this school is a man! ... Basically I went up the ladder and back down again! All by my personal choice, apart from one break related to health. I am now biding my time while I get back into it and am still looking around ... . (Primary class teacher, school ii)

Some female informants stated that they had never wanted to have the workload of a senior manager. One elaborated: 'I considered deputy headship, but it is the hardest job in the school!' (female primary teacher, school ii).

However, another informant in primary school iii suggested that more part-time management positions should be available in schools so that teachers who were 'passionate about (their) job' but also had a young family or other demands on their time could fulfil their potential. In fact, one older female promoted teacher vociferously extolled the advantages of part-time working:

I am the envy of everyone I know with two afternoons a week off! I am sticking to my guns! The Head keeps saying to me, wouldn't you like to go full-time? I have invested a lot of time and commitment in this school [so I wouldn't want to leave]. It suits me down to the ground. ... When I see my colleagues and what they've done, I'm sure I've made the right decision for me. I have colleagues who have gone up the ladder and others who have stayed at the same level. I have never had aspirations to join the management side. That's not what I wanted to do 'cause I wanted to work with children. I have to say that I have been asked to go for senior posts but I want to enjoy my job! (Primary class teacher, school vi)

Nonetheless, the positive advantage of being male in terms of teachers' careers was a recurring theme in the case study and special interest group discussions: [ $\mathrm{I}$ was] got at [as it was] rumoured that I only got the job because I was a man. (Promoted teacher in special school xviii) ... after only 7 years experience [he got the deputy post elsewhere]—but he was tall, handsome and looked the part. (Primary class teacher, school ii) Men expect promotion to happen. (Primary class teacher, school vii)

A few key implications from these findings are outlined below.

\section{Conclusion}

In spite of ongoing legislative reforms, there is little evidence from this study that the situation in terms of promotion for minority ethnic teachers is about to improve dramatically. In general, teacher retention and recruitment remains a recurring problem in some parts of England: over one-quarter want to leave the profession after having been in it for less than 5 years (MORI, 2001; Smithers \& 
Robertson, 2003). This study provides some evidence that improved pay and flexible conditions for some teachers who feel undervalued, such as women and those from minority ethnic groups, might encourage them to remain in the profession. Females in both primary and secondary case study schools perceived that their professional contribution was undervalued. This may be partly due to the fact that the relatively few male teachers in primary schools are usually encouraged to apply for promotion (Thorton \& Bricheno, 2000). Whether or not headteachers will be able to take advantage of the devolved school budgets to implement more flexible recruitment and retention strategies for suitable staff, who would otherwise be disenfranchized by the system, has yet to be established (Mahoney et al., 2004).

Overall, informants identified themselves first and foremost as a teacher (rather than for instance, as from a particular minority ethnic group or sex or some combination of both). Not surprisingly, the different groups of teachers produced somewhat distinct findings. Participants in the special interest groups and the school case studies were much more likely than survey respondents to suggest that age, disability, race and sex were important determinants of their professional circumstances. Nonetheless, most of the respondents saw age as a barrier to promotion. In secondary schools it was usually female informants who perceived that they were too old to apply for senior management posts. Although they are disproportionately male (DfES, 2003a), the number of teachers taking early retirement is on the increase again. The interrelationship between older teachers' health needs and job satisfaction in different school contexts warrants some investigation.

Few minority ethnic teachers are involved in senior management training initiatives organized by the government (Revell, 2003, p. 4). An NUT (2004) survey of black and minority ethnic teachers in senior management positions has also reinforced findings that minority ethnic group teachers feel they have to push themselves extra hard to prove that they are equal to other staff. The majority of minority ethnic survey respondents thought that race was a career-limiting factor. In agreement with other studies, the minority ethnic respondents perceived themselves to be held back unfairly in career terms and inhibited in gaining promotion (Siraj-Blatchford, 1993; Osler, 1997).

Even in London, where the minority ethnic population is greatest, there are still relatively few minority ethnic teachers employed in the schools. (Parker-Jenkins, 1998: Ross, 2001; Osler \& Morrison, 2002; Menter, 2004). Earley et al. (2004) have suggested that more female headteachers than male headteachers prefer to work in disadvantaged inner city schools. In-depth qualitative case studies within individual successful schools with mixed staff complements, from a range of social settings and geographic contexts are needed to shed light on the requisite processes for broadening the overall profile of the teaching profession in the 21st century.

\section{Acknowledgements}

The funding for this research came from the Department for Education and Skills (DfES) and is gratefully acknowledged. The authors would like to thank all of the research participants, including teachers and representatives from local authorities, professional associations and unions, for their valuable and insightful contributions.

The data collection and analysis was conducted by Julia Davidson, Janet Powney, Stuart Hall, Sheila Edward and Susan Kirk of the SCRE Centre in collaboration with Heidi Safia Mirza of the Centre for Racial Equality Studies. The final editing of the DfES report was the responsibility of Valerie Wilson. Marie Parker-Jenkins gave very useful feedback at a preliminary stage of the research. John Hall's painstaking comments on an early draft of this paper were much appreciated. Two anonymous referees also made very helpful suggestions. Of course, any errors are the first author, Julia Davidson's sole responsibility.

References 
Carrington, B. \& Tomlin, R. (2000) Towards a more inclusive profession, European Journal of Teacher Education, 23(2), 140-157.

Carrington, B., Bonnet, A., Demaine, J., Hall, I., Nayak, A., Short, G., Skelton, C., Smith, F. \& Tomlin, R. (2001) Ethnicity and the professional socialisation of teachers (London, Teacher Training Agency).

Department for Education and Skills (DfES) (2003a) School workforce in England 2002 (including teachers' pay for England and Wales) (London, Stationery Office).

Department for Education and Skills (DfES) (2003b) School workforce in England (including pupil:teacher ratios and pupil:adult ratios). Available online at: www.dfes.gov.uk/staatistics/ DB/SFR/ (accessed 28 February 2004).

Department for Education and Skills (DfES) (2004) School workforce in England: provisional teacher sickness absence in 2003 and teacher ethnicity 2004, first release. Available online at: www.dfes.gov/rsgateway/DB/SFR/ (accessed 1 August 2004).

Earley, P., Evans, J. \& Gold, A. (2004) Who'd be a head?, Managing

Schools Today, May/June, 55-58. Garner, R. (2002,

November 14) Male primary teacher may no longer be endangered, The

Independent, p. 13. Glaser, B. \& Straus, A. (1967) The discovery of grounded theory (New York, Aldine).

Howson, J. (2002, November 8) New take on gender gap, Times Educational Supplement, p. 32. Hutchings, M.

(2001) Towards a representative teaching profession: gender, paper presented at

the Towards a Representative Teaching Profession Seminar, Institute of Policy

Studies in Education, University of North London, 11 December. Maclean, R. (1992)

Teachers' careers and promotional patterns: a sociological analysis (London,

Falmer). McCreith, S. \& Ross, A. (2002) Ethnic minorities in the teacher workforce

(London, University of London).

Maylor, U., Dalgety, J. \& Ross, A. (2003) Minority ethnic teachers in England: a report for the General Teaching Council for England (London, GTCE). Available online at: www.gtce.org.uk/ BMEreport (accessed 21 February 2004).

Menter, I. (2004) Opening access for multiculturalism, Teaching Scotland, GTC

Scotland, 14, 18-19. Mahony, P., Menter, I. \& Hextall, I. (2004) The

emotional impact of performance-related pay on teachers in England, British

Educational Research Journal, 30(3), 435-456.

MORI (2001) Issues in the recruitment and retention of teachers: a survey conducted for the GTC by MORI. Available online at: www.gtce.org.uk/gtcinfo/mori.asp (accessed 12 February 2003).

National Statistics (2002a) Social focus in brief: ethnicity 2002 (London, Office for

National Statistics). National Statistics (2002b) Labour market experiences of people with disabilities, Labour Market Trends, August, 415-427.

National Union of Teachers (2001) Part-time teaching (London, NUT). Available online at: www.data.teachers.org.uk/pdfs/pt2000.pdf (accessed 15 February 2003).

National Union of Teachers (2004) Pushed to prove themselves more (London, NUT). Available online at: www.nut.org.uk (accessed 30 May 2004).

Osler, A. (1997) Black teachers as professionals: survival, success and subversion, Forum for Promoting 3-19 Comprehensive Education, 39(2), 55-59.

Osler, A. \& Morrison, M. (2002) Can race equality be inspected? Challenges for policy and practice raised by OfSTED school inspections framework, British Educational Research Journal, 28(3), 327-338.

Parker-Jenkins, M. (1998, January 16) Muslims gain equality of funding, Times Educational Supplement, p. 18.

Powney, J., Hall, S., Wilson, V., Davidson, J., Kirk, S., Edward, S. \& Mirza, H. (2003) Teachers' careers: the impact of age, disability, ethnicity, gender and sexual orientation (London, DfES).

Revell, P. (2003, January 14) Whitewash, The Guardian Education,p.4.

Ross, A. (2001) Towards a representative teaching profession: teachers from the ethnic minorities, paper presented at the Towards a Representative Teaching Profession Seminar, Institute of Policy Studies in Education, University of North London, 11 December.

Smithers, A. \& Robinson, P. (2003) Factors affecting teachers’ decisions to leave the profession, DfES research report (London, DfES).

Siarj-Blatchford, I. (1993) Race, gender and the education of teachers (Buckingham, UK, Open University).

Tinklin, T., Riddell, S. \& Wilson, A. (2003) Policy and provision for disabled students in higher education in Scotland and England (Perth, UK, SERA).

Thorton, M. \& Bricheno, P. (2000) Primary school teachers' careers in England and Wales: the relationship between gender, role and position and promotional aspirations, Pedagogy, Culture and Society, 8(2), 187-206. 
